\title{
Potentiation of general anaesthetic activity of ketamine by memantine
}

\author{
M. S. Umamageswari ${ }^{1 *}$, K. Vasanthan $^{2}$, T. M. Karthikeyan ${ }^{3}$
}

\author{
${ }^{1}$ Department of Pharmacology, ${ }^{3}$ Department of Pathology, KMCH Institute of Health Sciences and Research, \\ Coimbatore, Tamil Nadu, India \\ ${ }^{2}$ Karpagam Faculty of Medical Sciences and Research, Coimbatore, Tamil Nadu, India
}

Received: 23 October 2019

Revised: 09 December 2019

Accepted: 10 December 2019

\section{*Correspondence:}

Dr. M. S. Umamageswari,

Email: umakarthikm@gmail.com

Copyright: (c) the author(s), publisher and licensee Medip Academy. This is an open-access article distributed under the terms of the Creative Commons Attribution Non-Commercial License, which permits unrestricted non-commercial use, distribution, and reproduction in any medium, provided the original work is properly cited.

\section{ABSTRACT}

Background: The study was done with the objective to evaluate synergistic activity of ketamine induced general anesthesia by memantine in wistar albino rats.

Methods: The wistar albino rats of either sex were divided into four groups of five animals. Group 1 received ketamine $40 \mathrm{mg} / \mathrm{kg}$, group 2 received ketamine $80 \mathrm{mg} / \mathrm{kg}$, group 3 received ketamine $40 \mathrm{mg} / \mathrm{kg}$ along with memantine $10 \mathrm{mg} / \mathrm{kg}$ and group 4 received $80 \mathrm{mg}$ of ketamine along with memantine $10 \mathrm{mg} / \mathrm{kg}$ to evaluate the synergistic activity of ketamine induced general anesthesia by memantine. The sleep latency time and duration of sleep were measured in all the groups.

Results: The sleep latency time of group 4 is significantly decreased $(p<0.001)$ compared to all other groups. The duration of sleep of group 4 is significantly increased $(p<0.001)$ compared to group 1 and group 3 , but less than that of group 1 .

Conclusions: Memantine possess synergistic activity of ketamine induced general anaesthesia.

Keywords: Ketamine, Memantine, General anaesthesia

\section{INTRODUCTION}

Ketamine is a general anaesthetic agent which produces dissociative anesthesia. Dissociative anaesthesia is characterised by complete analgesia combined with amnesia and catatonia with or without loss of consciousness. It is an NMDA receptor antagonist. It acts on the cerebral cortex, particularly limbic system. In sub narcotic doses it has analgesic property. ${ }^{1}$ Low dose ketamine can also be used as an anti-depressant in refractory cases. ${ }^{2}$

Memantine is an uncompetitive NMDA receptor antagonist. It protects the neurons from glutamateinduced excitotoxicity. It is used as an adjunct or an alternative to cholinesterase inhibitor in Alzheimer's disease and other types of dementia. It delays the clinical deterioration in patients with moderate-severe Alzheimer's disease. ${ }^{3,4}$

NMDA receptor is a pentamer which is a ligand gated ion channel. It is composed of two different subunits and has six modulatory sites. It shows high permeability to $\mathrm{Ca}^{2+}$ and $\mathrm{Na}^{+}$. It is distributed in the wider areas of brain including spinal cord, hippocampus, cerebral cortex and glial cells. One of the modulatory sites of NMDA receptor is a site within the channel that binds phencyclidine, ketamine and memantine. NMDA receptor plays an important role in long term adaptive changes like synaptic plasticity as well as pathological changes like excitotoxicity in brain. It also plays an important role in learning and memory. Over stimulation 
of NMDA receptor results in excitotoxicity in brain, that leads to apoptosis and neurodegeneration. ${ }^{3,5}$

The channel-blocking NMDA antagonists broadly fall into two categories. They are dissociative anesthetic-like agents and low-affinity antagonists. Dissociative anesthetics at low doses cause hyperlocomotion, stereotypies and ataxia; at higher anesthetic doses they induce a state of immobility, analgesia, and amnesia. ${ }^{5}$

\section{Aims and objectives}

The primary objective of this study was to evaluate the potentiation of general anesthetic activity of ketamine by memantine and the secondary objective was to evaluate the potentiation of general anaesthetic activity of low dose ketamine by memantine.

\section{METHODS}

\section{Animals}

In our study 20 wistar albino rats of either sex weighing $120-150 \mathrm{~g}$ were used. All the animals were allowed for free access of water, food, and ad libitum All the animals were housed at a temperature of $28 \pm 2^{\circ} \mathrm{C}$, and dark: light cycle of 12:12 hr. The research was started after the Institutional Animal Ethical Committee (IAEC) approval (IAEC-3/Pharmacology/05/16)).

\section{Grouping}

All the animals were divided into 4 groups of 5 animals each with $90 \%$ of confident interval.

Group 1: Received $0.5 \mathrm{ml}$ of distilled water orally and ketamine $40 \mathrm{mg} / \mathrm{kg}$ i.p. ${ }^{6}$

Group 2: Received $0.5 \mathrm{ml}$ of distilled water orally and ketamine $80 \mathrm{mg} / \mathrm{kg}$ i.p.

Group 3: Received memantine $10 \mathrm{mg} / \mathrm{kg}$ orally and ketamine $40 \mathrm{mg} / \mathrm{kg}$ i.p. ${ }^{7}$

Group 4: Received memantine $10 \mathrm{mg} / \mathrm{kg}$ orally and ketamine $80 \mathrm{mg} / \mathrm{kg}$ i.p.

Minimal handling was done to avoid stress and suffering of the animals. To avoid external stimuli to animals, experiments were conducted in a quiet place with dim light.

\section{Drugs}

Drugs used in this study are memantine (crescent), ketamine (neon), and distilled water. Ketamine was used to induce general anesthesia. Low dose ketamine is used in the dose of $40 \mathrm{mg} / \mathrm{kg}$ and high dose ketamine is used in the dose of $80 \mathrm{mg} / \mathrm{kg}$. It is given through intraperitoneal (i.p.) route. Dose of memantine is chosen according to the research by Lee et al. ${ }^{7}$ Distilled water and test drug memantine was given through oral route. Normal saline was used to dissolve the test drug. Just before the experiment, drug solutions were prepared freshly. Intra peritoneal injection dose and oral dose is calculated according to the formula: ${ }^{8}$

Dose $(\mathrm{g})=\frac{\text { Animal weight }(\mathrm{g}) \times \text { Animal dose }(\mathrm{mg})}{1000 \mathrm{~g}}$

\section{Assessment of potentiation of general anaesthetic activity of ketamine}

The method employed in this study was described by Vogel. ${ }^{9}$ All the test drugs were given orally after $12 \mathrm{hr}$ fasting. After $1 \mathrm{hr}$ of administration of test drugs, ketamine $(40 \mathrm{mg} / \mathrm{kg}$ or $80 \mathrm{mg} / \mathrm{kg}$, i.p.) was given to induce sleep. The onset time of sleep (loss of righting reflex) was noted for all the animals. After induction of sleep, rats were placed in its back. At the end of sleep cycle, the animals come to its normal posture (recovery of righting reflex). The time interval between the intraperitoneal injection of ketamine and start of sleep was recorded as latency time ( $\mathrm{min}$ ). The interval between loss of righting reflex and recovery of righting reflex was measured as sleeping time ( $\mathrm{min})$.

\section{Statistical analysis}

Software ANOVA followed by post hoc test was used to analyze the data. In this study $\mathrm{p}<0.05$ was considered as significant. All the results found were expressed as Mean \pm SEM.

\section{RESULTS}

Table 1 shows the onset lag time and duration of sleep. Group 1 showed 6.4 \pm 0.4 min onset lag time. Compared to group 1, Group 2 showed significant reduction in onset lag time (3.6 $\pm 0.24 \mathrm{~min})$. Group 3 showed $3.4 \pm 0.92 \mathrm{~min}$ of onset lag time which is almost equal to ketamine $80 \mathrm{mg}$ group. Group 4 showed highly significant reduction $(p<0.001)$ in onset lag time $2 \pm 0.447$ min compared to other three groups.

The duration of sleep of ketamine $40 \mathrm{mg}$ group is $16.8 \pm 1.46 \mathrm{~min}$. Ketamine $80 \mathrm{mg}$ group showed highly significant $(\mathrm{p}<0.001)$ increase in duration of sleep $(80.6 \pm 2.78 \mathrm{~min})$ compared to all other groups. Group 3 (ketamine $40 \mathrm{mg}$ and memantine $10 \mathrm{mg}$ ) showed significant increase in duration of sleep (21.4 $\pm 2.97 \mathrm{~min})$ compared to group 1, but less than that of group 2 and 4 . Duration of sleep of group 4 is significantly increased compared to group 1 and 3 but less than that of group 2 . 
Table 1: Onset lag time and duration of sleep.

\begin{tabular}{|llll|}
\hline Groups & Drugs & Onset lag time & Duration of sleep \\
\hline Group 1 & Ketamine $40 \mathrm{mg}$ & $6.4 \pm 0.4$ & $16.8 \pm 1.46$ \\
\hline Group 2 & Ketamine $80 \mathrm{mg}$ & $3.6 \pm 0.24 * *$ & $80.6 \pm 2.78^{* * *}$ \\
\hline Group 3 & Ketamine $40 \mathrm{mg}+$ memantine $10 \mathrm{mg}$ & $3.4 \pm 0.92^{* *}$ & $21.4 \pm 2.97 * *$ \\
\hline Group 4 & Ketamine $80 \mathrm{mg}+$ memantine $10 \mathrm{mg}$ & $2 \pm 0.447 * *$ & $57 \pm 7.83^{* * *}$ \\
\hline
\end{tabular}

\section{DISCUSSION}

NMDA receptor antagonists are commonly used in Parkinsonism, influenza (amantadine), alzheimer's disease (memantine), anticonvulsant (eliprodil). Memantine is a non-competitive and use dependent antagonist of NMDA receptors. ${ }^{10}$

Ketamine is a short-acting anaesthetic drug without serious undesirable side effects, such as respiratory or cardiovascular depression. $^{11}$

In our previous study we found that Amantadine, a NMDA receptor antagonist accentuates the general anaesthetic activity of ketamine $40 \mathrm{mg} / \mathrm{Kg}$ and ketamine $80 \mathrm{mg} / \mathrm{kg}$. Memantine is structurally similar to amantadine, with the exception of two methyl groups that are substituted for carbon atoms at the 3-and 5-positions. ${ }^{5}$ So we aimed this study to find out the synergistic activity of memantine and ketamine. Even though memantine's structure is similar to amantadine, synergistic action of memantine is lesser than that of amantadine. Morris et al also stated in their study that, like many other NMDA antagonists, memantine behaves as a dissociative anaesthetic at supratherapeutic doses. ${ }^{12}$ Memantine did not potentiate the duration of sleep of ketamine $80 \mathrm{mg} / \mathrm{kg}$ similar to that of amantadine.

Ishikawa et al studied the effects of memantine on sleep architecture. In this research they investigated the effects of memantine on polysomnography (PSG) variables and Behavioural and psychological symptoms of dementia. They included 12 patients in this study, all the patients received $20 \mathrm{mg} /$ day memantine. PSG demonstrated a longer total sleep time $\mathrm{p}<0.01$, increases in sleep efficiency $(p<0.01)$ and time spent in stage II. They also found that memantine decreased nocturnal awakening, the periodic limb movement index, and time spent in stage I. They have concluded that memantine was effective in reducing fragmented sleep. ${ }^{13}$

Ishida et al hypothesized that memantine may be useful for the treatment of excessive daytime sleepiness. They studied the effect of memantine on excessive sleepiness after $6 \mathrm{~h}$ of sleep deprivation in adult rats. They compared the effect with methylphenidate. They also evaluated the involvement of the dopaminergic system in the wakefulness-promoting effect of memantine. They chronically implanted electrodes for electroencephalogram (EEG) and electromyogram (EMG) into the cortex and dorsal neck muscle of adult male rats and recorded EEG and EMG. They observed compensatory excessive sleepiness after sleep deprivation, memantine and methylphenidate caused a significant increase of sleep latency compared with the control group. They also found out that memantine increased total awake time and significantly decreased total non-rapid eye movement sleep and rapid eye movement sleep times. Although the effect of memantine was significantly suppressed by $\mathrm{D}_{1}$ receptor antagonist SCH 23390 (0.1 mg/kg, i.p.), $\mathrm{D}_{2}$ receptor antagonist raclopride had no antagonistic effect $(1 \mathrm{mg} / \mathrm{kg}$, i.p.). From these results, they concluded that the effect of memantine on sleepiness after sleep deprivation was similar to that of methylphenidate, and $D_{1}$ receptor may be involved in the effect of memantine. ${ }^{14}$

Naoyuki et al, observed two cases of sustained unconsciousness after long term use of memantine. Both cases developed consciousness disturbance after long term administration of memantine. One case showed myoclonus in the extremities. MRI, and electroencephalogram did not show any potential cause of consciousness disturbance and myoclonus other than memantine. They concluded that elevated blood concentration of memantine may be responsible for the unconsciousness in those cases. They compared their results with mechanism of ketamine, and postulated that memantine exerts a sedative effect in a similar manner to ketamine. They also concluded the case report with an advice to take care of elderly and renal failure patients when memantine is administered. ${ }^{15}$

Emik et al studied intraperitoneal administration of memantine on recovery, cognitive functions, and pain after propofol anaesthesia in female Wistar albino rats. They found that the duration of recovery of memantine and propofol group (Group MP) was significantly shorter than the propofol alone group (Group P) $(\mathrm{p}<0.001)$. They concluded that memantine provided shorter recovery times, better cognitive functions, and reduced postoperative pain. The authors deduced from this study that early recovery from propofol anesthesia, is due to the common interaction of both agents on the NMDA receptor rather than to an increase in the elimination rate. $^{16}$ Our study also showed that the recovery of ketamine $80 \mathrm{mg}$ and memantine $10 \mathrm{mg}$ is faster as compared to that of ketamine $80 \mathrm{mg}$ alone. This effect might be due to common interaction of both agents on NMDA receptor rather than the elimination rate. Johnson et al and Sabino et al found that pharmacokinetic 
differences between ketamine and memantine do not make a major contribution to their differential behavioral effects in rodents. ${ }^{17,18}$

Rahimzadeh et al compared efficacy of oral memantine inpost operative pain relief in patients undergoing dacryocystorhinostomy. They deduced that sedation scale one hour after the operation was significantly greater in the memantine $20 \mathrm{mg}$ group than the placebo $(\mathrm{p}<0.001)$. The sedation scores in 6 hours after the surgery were similar in both groups. The authors concluded that, memantine can be administered to patients whose condition and type of operation allows early discharge. ${ }^{19}$

The onset lag time of ketamine $40 \mathrm{mg} / \mathrm{kg}$ and memantine $10 \mathrm{mg} / \mathrm{kg}$ is almost equal to ketamine $80 \mathrm{mg} / \mathrm{kg}$. The onset lag time is significantly reduced by ketamine 80 $\mathrm{mg} / \mathrm{Kg}$ and memantine $10 \mathrm{mg} / \mathrm{kg}$ combination compared to all other group. This shows that memantine potentiates the onset lag time of ketamine in both doses.

NMDA receptor antagonistic activity at the cortex and subcortical area of brain where ketamine acts is the cause of potentiation of actions of ketamine by memantine. ${ }^{20}$

In our study we only monitored the latency time and the duration of sleep. Respiratory rate, cardiac activity, locomotor activity and electro encephalography during the anaesthesia were not monitored. We didn't study the effects after recovery from anesthesia.

\section{CONCLUSION}

Memantine potentiates the actions of ketamine. The recovery from high dose ketamine and memantine is faster than with high dose of ketamine. This might be due to its effect on other receptors. Further studies are needed to prove its effects on behavioural changes, cognitive function and locomotor activity after recovery.

Funding: No funding sources

Conflict of interest: None declared

Ethical approval: The study was approved by the Institutional Ethics Committee

\section{REFERENCES}

1. Srivastava SK. Pharmacology for MBBS. 1st ed. New Delhi: Avichal Publishing Company; 2017.

2. Williams NR, Heifets BD, Blasey C, Sudheimer K, Pannu J, Pankow H, et al. Attenuation of Antidepressant Effects of Ketamine by Opioid Receptor Antagonism. Am J Psychiatr. 2018;175(12):1205-15.

3. McNamara JO. Pharmacotherapy of the Epilepsies. In: Brunton L, Chabner B, Knollman B, eds. Goodman \& Gilman's the Pharmacological Basis of Therapeutics. 12th ed. New Delhi: McGraw Hill Medical; 2011.
4. Cottone $\mathrm{P}$, Iemolo A, Narayan AR, Kwak J, Momaney D, Sabino V. The uncompetitive NMDA receptor antagonists ketamine and memantine preferentially increase the choice for a small, immediate reward in low-impulsive rats. Psychopharmacology (Berl). 2013;226(1):127-38.

5. Rogawski MA, Wenk GL. The Neuropharmacological Basis for the Use of Memantine in the Treatment of Alzheimer's Disease. CNS Drug Rev. 2003;9(3):275-308.

6. Guidelines for anesthesia and analgesia in laboratory animals. Suny upstate medical university department of laboratory animal resources. Available at: http://www.upstate.edu/dlar/pdf/anesthesia_analgesia _guidelines.pdf. Accessed on 3 September 2016.

7. Lee SH, Kim SH, Noh YH, Choi BM, Noh GJ, Park WD, et al. Pharmacokinetics of Memantine after a Single and Multiple Dose of Oral and Patch Administration in Rats. Basic Clin Pharmacol Toxicol. 2016;118(2):122-7.

8. Erhirhie EO, Ekene, Nwoke E, Ajaghaku DL. Guidelines on dosage calculation and stock solution preparation in experimental animals' studies. J Natural Sci Res. 2014;4(18):100-6.

9. Vogel GH, Vogel WH, Ascholkens B, Sandow J, Muller G, Wolfgang F. Vogel Drug Discovery and Evaluation. (2nd ed.). Berlin: Springer Verlag; 2002: 495-496.

10. Zorumski CF, Izumi Y, Mennerick S. Ketamine: NMDA Receptors and Beyond. J Neurosci. 2016;36(44):11158-64.

11. MiyasakaM, Domino E F. Neuronal mechanisms of ketamine-induced anesthesia. Int $\mathbf{J}$ Neuropharmacol. 1968;7:557-73.

12. Morris H, Wallach J. From PCP to MXE: a comprehensive review of the non-medical use of dissociative drugs. Drug Testing and Analysis. 2014;6(7-8):614-32.

13. Ishikawa I, Shinno H, Ando N, Mori T, Nakamura Y. The effect of Memantine on sleep architecture and psychiatric symptoms in patients with Alzheimer's disease. Acta Neuropsychiatr. 2016;28(3):157-64.

14. Ishida T, Obara Y, Kamei C. Studies on wakefulness promoting effect of Memantine in rats. Behavioural Brain Res. 2010;206(2):274-8.

15. Naoyuki K, Michio S. Memantine-induced sustained unconsciousness. Neurol Clin Neurosci. 2016;4(6):236-8.

16. Emik U, Unal Y, Arslan M, Demirel CB. The effects of memantine on recovery, cognitive functions, and pain after propofol anesthesia. Revista Brasileira De Anestesiologia. 2016;66(5):485-91.

17. Johnson JW, Kotermanski SE. Mechanism of action of memantine. Curr Opin Pharmacol. 2006;6(1):61-7.

18. Sabino V, Narayan AR, Zeric T, Steardo L, Cottone P. mTOR activation is required for the anti-alcohol effect of ketamine, but not memantine, in alcoholpreferring rats. Behav Brain Res. 2013;247:9-16.

19. Rahimzadeh P, Imani F, Nikoubakht N, Koleini Z, Reza Faiz SH, Sayarifard A. A Comparative Study 
on the Efficacy of Oral Memantine and Placebo for Acute Postoperative Pain in Patients Undergoing Dacryocystorhinostomy (DCR). Anesthesiol Pain Med. 2017;7(3):e45297.

20. Iversen L, Dargan P. Ketamine: a review of use and harm. London: Advisory Council on the Misuse of Drugs; 2010.
Cite this article as: Umamageswari MS, Vasanthan K, Karthikeyan TM. Potentiation of general anaesthetic activity of ketamine by memantine. Int $\mathrm{J}$ Basic Clin Pharmacol 2020;9:146-50. 